\title{
NILAI PENDIDIKAN KARAKTER DALAM PEMBELAJARAN IPS DI SEKOLAH DASAR
}

\author{
Yulia Siska $^{1)}$, Yufiarti ${ }^{2)}$, Muhammad Japar ${ }^{3)}$ \\ ${ }^{1}$ Program Pascasarjana, Universitas Negeri Jakarta \\ ${ }^{2}$ Program Pascasarjana, Universitas Negeri Jakarta \\ ${ }^{3}$ Program Pascasarjana, Universitas Negeri Jakarta \\ yuliasiska1985@gmail.com
}

\begin{abstract}
This study conducted an empirical study of the implementation of the value of character education in social studies learning at SDN 1 Gunung Terang, Bandarlampung. This study uses a qualitative descriptive design with content analysis techniques. Based on the results and discussion, it is stated that: 1) The process of implementing the value of character education in SDN 1 Gunung Terang, Bandarlampung consists of the planning, implementation, and evaluation stages; and 2) The suitability of integrated thematic books with character education includes religious character, tolerance, discipline, creative, democratic, curiosity, national spirit, respect for achievement, friendship, enjoy reading, and care for the environment.
\end{abstract}

Keywords: character, social studies learning, thematic

\section{PENDAHULUAN}

Penanaman nilai karakter dapat dilakukan melalui pendidikan di sekolah, pendidikan dalam lingkup keluarga, dan masyarakat. Pendidikan di sekolah tidak hanya menuntut siswanya sukses dalam pelajaran dan memiliki prestasi yang tinggi, tetapi juga mempunyai sikap dan perilaku yang baik. Sekolah memainkan peran penting dan memiliki tanggung jawab mutlak dalam menanamkan dan mengembangkan nilai karakter. Pendidikan karakter di sekolah diarahkan pada nilai-nilai yang dianggap relevan bagi tumbuh kembang siswa, seperti sikap dan perilaku disiplin, jujur, tanggung jawab, rasa hormat, adil, toleransi, dan lain-lain.

Pendidikan karakter merupakan pendidikan nilai, budi pekerti, moral, dan pendidikan watak. Lickona (1991: 50-52) mengartikan bahwa watak atau karakter sebagai suatu perpaduan yang harmonis dari berbagai kebajikan yang tertuang dalam agama, sastra, pandangan kaum cerdik-pandai dan manusia pada umumnya sepanjang zaman. Oleh karena itu, Lickona memandang karakter atau watak itu memiliki tiga unsur yang saling berkaitan, yakni moral knowing, moral feeling, and moral behavior atau konsep moral, rasa dan sikap moral dan 


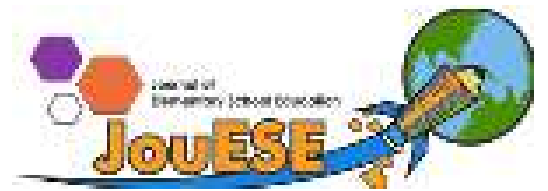

perilaku moral. Adapun penelitian ini dibatasi pada sembilan jenis karakter dalam kajiannya, yaitu nilai kejujuran, toleransi, kerja keras, ingin tahu, kreatif, bersahabat, peduli sosial, cinta damai, dan bertanggung jawab. Pendidikan karakter, budi pekerti, dan budaya, dalam buku teks pelajaran digali berdasar aspek teks itu sendiri. Pendidikan karakter dalam buku teks pembelajaran IPS diaplikasikan (teks/konteks) sebagai usaha mengubah sikap dan perilaku siswa ke arah kedewasaan untuk memperoleh keseimbangan antara hubungan akal dan perasaan. Hal tersebut akan mewujud pada keselarasan budaya berinteraksi dalam masyarakat yang disebut Lynch (dalam Syamsiyatun dan Wafiroh (ed), 2013: 208) sebagai sistem tentang cara hidup, berperilaku, berpikir, dan cara berhubungan dengan orang lain. Oleh karena itu, dapat dikatakan bahwa budaya turut menentukan cara pandang seseorang dalam bertindak atau berperilaku dengan unsur pembentuknya adalah nilai (values).

Penanaman dan pengembangan pendidikan karakter di sekolah menjadi tanggung jawab bersama. Pendidikan karakter dapat dintegrasikan dalam pembelajaran pada setiap mata pelajaran. Penanaman dan pengembangan nilai karakter di sekolah dapat dilakukan dalam proses pembelajaran, yaitu implementasi pada mata pelajaran tertentu. Mata pelajaran atau materi yang dianggap sesuai sebagai wahana penanaman nilai karakter di sekolah adalah pembelajaran atau mata pelajaran IPS khususnya pada jenjang Sekolah Dasar (SD). Sekolah harus melengkapi sarana penunjang yang tersedia dalam menanamkan nilai-nilai pendidikan karakter, Hal itu diharapkan dapat memberikan pengetahuan kepada siswa untuk menangani hambatan-hambatan yang terjadi dalam kehidupan di masyarakat, salah satunya adalah buku teks (Sukmadinata, 2013: 95).

Buku ajar yang berlaku di sekolah-sekolah pada saat ini mengacu pada Kurikulum 2013. Kurikulum 2013 (K-13) sebagai kurikulum nasional telah diberlakukan pemerintah untuk pembaruan dan pengembangan Kurikulum Tingkat Satuan Pendidikan (KTSP). Kurikulum pembelajaran di berbagai jenjang pendidikan, dari dasar sampai menengah atas pada saat ini mengadopsi Kurikulum 2013 yang dikembangkan dengan penyempurnaan pola pikir dari pembelajaran pasif menjadi pembelajaran kritis. 


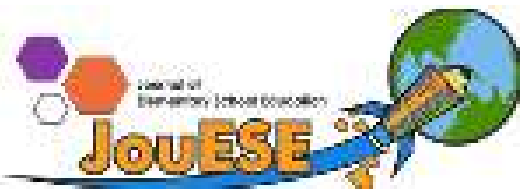

Pembelajaran ilmu sosial dalam kurikulum 2013 terdapat empat perubahan penting dibanding kurikulum sebelumnya. Perubahan tersebut meliputi Standar Kompetensi Lulusan (SKL), Standar Proses, Standar Isi, dan Standar penilaian. Kompetensi Inti merupakan operasionalisasi SKL, yaitu kualitas yang harus dimiliki siswa/peserta didik yang telah menyelesaikan pendidikan pada jenjang pendidikan tertentu. Gambaran kompetensi utama dikelompokkan ke dalam aspek sikap, pengetahuan, dan keterampilan (afektif, kognitif, dan psikomotor) yang harus dipelajari peserta didik untuk suatu jenjang sekolah, kelas dan mata pelajaran. Kompetensi Inti (KI) harus menggambarkan kualitas yang seimbang antara pencapaian hard skills dan soft skills. Kompetensi Dasar merupakan muatan atau kompetensi yang terdiri atas pengetahuan, sikap, dan keterampilan yang bersumber dari KI yang harus dikuasai siswa. Kompetensi tersebut dikembangkan dengan memperhatikan karakteristik siswa, kemampuan awal, dan ciri suatu mata pelajaran (Kawuryan, 2013: 13). Menurut Yulia Siska (2018: 31-40), ketercapaian tujuan mata pelajaran IPS didukung oleh proses pembelajaran yang dirancang dalam Kurikulum 2013 dan berlaku juga untuk IPS. Ada dua hal dalam pembelajaran IPS yaitu pendekatan pengembangan materi ajar yang selau dikaitkan dengan lingkungan masyarakat di satuan pendidikan dan model pembelajaran yang dikenal dengan istilah pendekatan saintifik.

Buku teks dapat dijadikan acuan, baik bagi guru maupun siswa; baik sebagai sumber utama maupun menjadi buku suplemen/tambahan. Buku pelajaran dapat didefinisikan sebagai media pembelajaran (instruksional) yang dominan peranannya di kelas, media penyampaian materi kurikulum, dan bagian sentral dalam suatu sistem pendidikan (Efendi, 2009: 320-333). Terdapat beberapa istilah yang terkait dengan buku pelajaran, seperti (a) buku bacaan, (b) buku sumber, dan (c) buku pegangan dalam dunia pendidikan. Adapun kategori utama dalam menganalisis kualitas buku adalah: a) Kelayakan isi yang diperinci dengan adanya keterangan kesesuaian materi dengan $\mathrm{KI} / \mathrm{KD}$, keakuratan materi, kemutakhiran materi, mendorong keingintahuan, praktikum dan kewirausahaan, pengayaan; b) Kelayakan bahasa ditinjau dari aspek lugas, komunikatif, dialogis dan interaktif, kesesuaian dengan perkembangan peserta 


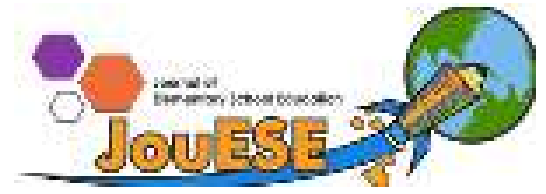

didik, kesesuaian dengan kaidah bahasa Indonesia; dan c) Kelayakan penyajian, lebih rinci adanya teknik penyajian, pendukung penyajian, pembelajaran, dan koherensi alur berpikir (Cunningsworth, 1995: 3; Brown, 2000: 142; Harmer, 2003: 118; Sofyan, 1997:7). Buku tematik terpadu di SD mengacu yang Kurikulum 2013 disesuaikan dengan rancangan pembelajaran untuk mencapai kompetensi yang diharapkan. Pencapaian kompetensi tersebut menuntut pendekatan pembelajaran tematik terpadu, yaitu mempelajari semua mata pelajaran secara terpadu melalui tema-tema kehidupan yang dijumpai siswa sehari-hari.

Buku teks sekolah yang digunakan dalam pembelajaran ditulis berdasarkan standar kompetensi dan kompetensi dasar sebagaimana yang tercantum dalam standar isi (Mulyana, 2009: 1-14). Buku teks yang dijadikan subjek penelitian ini adalah Buku Tematik Terpadu Kelas V SD. Buku Kurikulum Nasional SD Kelas V di dalamnya dirumuskan secara terpadu mengenai kompetensi sikap, pengetahuan, dan keterampilan yang harus dikuasai siswa. Kompetensi yang diharapkan dari lulusan SD adalah kemampuan berpikir dan bertindak produktif serta kreatif, baik secara abstrak maupun konkret.

Buku Seri Pembelajaran Tematik Terpadu untuk Siswa Kelas V SD telah disusun berdasarkan rumusan tema-tema di atas. Buku tematik terpadu merupakan penjabaran hal-hal yang harus dilakukan siswa untuk mencapai kompetensi yang diharapkan. Sesuai dengan pendekatan Kurikulum 2013, siswa diajak mencari sumber belajar lain yang tersedia dan terbentang luas di sekitarnya. Peran guru dalam meningkatkan dan menyesuaikan daya serap siswa dengan ketersediaan kegiatan pada buku ini sangat penting. Guru dapat memperkaya dengan kreasi dalam bentuk kegiatan lain yang sesuai dan relevan yang bersumber dari lingkungan alam, sosial, dan budaya.

Berdasarkan latar belakang yang telah diuraikan, peneliti melakukan kajian secara empiris mengenai Nilai Pendidikan Karakter dalam Pembelajaran IPS di SDN 1 Gunung Terang, Bandarlampung. Keutamaan dalam penelitian ini terletak pada pembahasan secara mendalam mengenai nilai pendidikan karakter dalam Buku Tematik Terpadu Kurikulum 2013 pada materi IPS untuk SD kelas $\mathrm{V}$ di Bandarlampung. Adapun tujuan penelitian ini adalah untuk memperoleh 
data empiris mengenai implementasi nilai pendidikan karakter dalam pembelajaran IPS SD di Bandarlampung. Secara lebih rinci, dirumuskan tujuan penelitian meliputi: 1) Mendeskripsikan implementasi nilai-nilai pendidikan karakter pada jenjang SD; dan 2) Menganalisis secara mendalam nilai pendidikan karakter dalam buku tematik terpadu pada materi IPS untuk SD kelas V. Penelitian ini diharapkan mampu memberikan sumbangan pemikiran dalam pembelajaran IPS terkait kesesuaian buku teks dengan kurikulum yang diwujudkan dalam buku ajar.

\section{METODE PENELITIAN}

Penelitian ini menggunakan desain deskriptif kualitatif dengan teknik analisis isi. Peneliti mendeskripsikan secara sistematis, faktual, dan akurat mengenai fakta-fakta dan hubungan kausal fenomena yang diteliti. Untuk memahami makna dari benda-benda atau fenomena sosial, penelitian kualitatif menekankan sifat realita yang terbangun secara sosial, hubungan erat antara peneliti dengan subjek yang diteliti, dan tanpa melupakan situasi yang membentuk penyelidikan. Penelitian bertumpu pada asumsi intersubjektivitas dan secara umum menciptakan makna dan "realitas" antara peneliti dengan partisipan.

Metode pengambilan sampel yang digunakan adalah purposive sampling, yang berarti sampel tersebut ditentukan dengan pertimbangan tertentu (Sugiyono, 2012: 61). Pemilihan sekelompok subjek dalam purposive sampling, didasarkan pada ciri-ciri tertentu yang dipandang mempunyai sangkut paut yang erat dengan ciri-ciri populasi yang sudah diketahui sebelumnya. Sampel yang digunakan dalam penelitian ini adalah kepala sekolah sebanyak 1 orang. Guru yang ditunjuk langsung oleh Kepala Sekolah, yaitu guru Wali Kelas V sebanyak 1 orang.

Data primer penelitian ini berupa buku tematik untuk materi IPS SD kelas Vsesuai dengan Kurikulum 2013 (Revisi 2017). Data primer tersebut digunakan untuk mengidentifikasi data nilai-nilai pendidikan karakter dan kesesuaian isi buku dengan kurikulum 2013. Selain itu, digunakan sebagai pedoman dalam mengetahui persepsi guru kaitannya dengan pengimplementasian nilai pendidikan karakter dalam pembelajaran IPS. Pemeriksaan keabsahan 
data peneliti ini menggunakan teknik triangulasi data sebagai berikut. Pertama, peneliti terlibat langsung dalam penelitian ini sekaligus sebagai instrument penelitian. Kedua, ketelitian dan ketekunan peneliti. Ketiga, kecukupan teori. Keempat, melakukan triangulasi teori. Kelima, triangulasi pakar, yakni melakukan wawancara dengan guru, diskusi dengan teman sejawat.

\section{HASIL DAN PEMBAHASAN}

\section{A. Implementasi Nilai-nilai Karakter di SDN 1 Gunung Terang}

Sumber data dalam proses pengambilan data melalui wawancara adalah "M" selaku kepala sekolah dan "R" merupakan guru kelas V yang ditunjuk oleh pihak sekolah. Dari hasil wawancara dan dokumentasi terlihat bahwa sekolah memiliki komitmen yang baik dalam menanamkan dan mengembangkan nilai- nilai karakter. SDN 1 Gunung Terang tampak memiliki komitmen yang tinggi dalam menanamkan dan mengembangkan nilai-nilai karakter. Hal tersebut terlihat dari visi dan misi sekolah, fasilitas sekolah yang baik, dan kondisi sekolah yang cukup rapi, bersih, dan nyaman.

Tahap perencanaan pada proses implementasi nilai-nilai p endidikan karakter di SDN 1 Gunung Terang berbeda, yaitu dengan perencanaan guru tidak membuat rencana pelaksanaan pembelajaran. Akan tetapi, implementasi nilai- nilai karakter ini dibudayakan atau disisipkan dalam semua mata pelajaran dan kegiatan sehari-hari di sekolah. Dengan demikian, diharapkan proses implementasi pendidikan karakter dapat terintegrasi dalam setiap kegiatan pembelajaran di sekolah. Dalam perencanaan, pihak sekolah juga melakukan sosialisasi terlebih dahulu kepada seluruh elemen sekolah, sehingga proses implementasi pendidikan karakter dapat berjalan sesuai dengan tujuan sekolah. Dimensi nilai karakter yang menjadi prioritas di SDN 1 Gunung Terang antara lain: religius, jujur, tekun, disiplin, dan peduli/tanggung jawab.

Implementasi nilai-nilai karakter di SDN 1 Gunung Terang di mulai saat siswa berangkat ke sekolah. Siswa diwajibkan maksimal hadir 5 (lima) menit sebelum bel masuk berbunyi. Siswa yang terlambat lebih dari 15 menit akan mendapatkan sanksi berupa hafalan surat. Setelah bel berbunyi, guru meminta ketua kelas untuk memimpin doa dan siswa diwajibkan mengikuti apel motivasi 


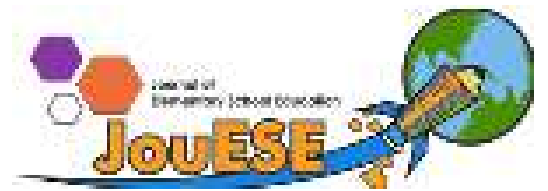

serta melaksanakan shalat dhuha. Hal ini dillakukan untuk membiasakan siswa memiliki nilai karakter religius dengan datang tepat waktu. Guru menekankan nilai karakter jujur, tekun, disiplin dan tanggung jawab dalam pelaksanaan pembelajaran. Nilai karakter jujur dilakukan guru dengan menyisipkan nasihat kepada siswa untuk berkata jujur, saat mengerjakan soal ulangan siswa diminta untuk tidak meminta jawaban kepada teman dan apabila membeli di kantin, siswa diwajibkan membayar sesuai apa yang dibeli. Nilai karakter tekun juga diajarkan oleh guru saat mengajar dengan menekankan kepada siswa untuk mengerjakan tugas dengan baik, memilik catatan pelajaran yang lengkap sehingga mudah dipelajari dan menyimak dengan baik pelajaran yang disampaikan guru. Nilai karakter peduli/tanggung jawab di SDN 1 Gunung Terang menekankan pada perilaku untuk membuang sampah pada tempatnya, memungut sampah yang berserakan dan membersihkan kamar mandi setelah menggunakannya.

Nilai karakter religius, jujur, tekun, disiplin, dan peduli/tanggung jawab yang telah di implementasikan oleh guru ternyata dalam praktiknya masih ada beberapa kendala yang harus dihadapi. Masih ada beberapa anak yang belum bisa menerapkan nilai-nilai karakter religius, jujur, tekun, disiplin, dan peduli/tanggung jawab di sekolah maupun dirumah. Hal tersebut nampak dengan masih ada siswa yang mencontek saat ulangan, masih ada siswa yang lupa dalam mengerjakan tugas-tugas, masih ada siswa yang mengobrol dengan temannya saat pelajaran di kelas, dan lainnya. Diperlukan kerjasama dengan berbagai pihak, baik pihak sekolah, keluarga maupun masyarakat agar berjalan sesuai dengan tujuan dalam proses implementasi pendidikan karakter. Oleh karena itu, pihak sekolah perlu menjalin komunikasi yang baik dengan berbagai pihak sebagai sarana sharing dan evaluasi untuk mendiskusikan permasalahan dan kendala yang terjadi saat proses pelaksanaan serta solusi untuk mengatasi permasalahan yang terjadi dalam proses implementasi nilai karakter. Pemecahan masalah yang diupayakan sekolah di antaranya adalah mengadakan kegiatan parenting school secara rutin untuk mengontrol perkembangan anak, komunikasi wali kelas kepada orang tua secara intensif atas masalah siswa yang dialami di sekolah, adanya pendampingan akademik, dan 


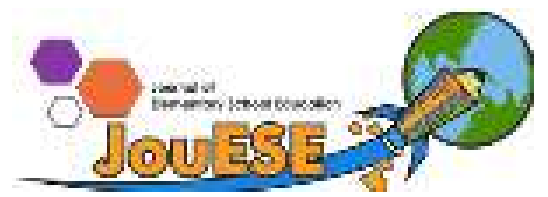

menjalin kedekatan antara guru dengan siswa untuk menggali masalah siswa dan upaya mencari solusi dan pemecahannya.

B. Kesesuaian Buku Tematik Terpadu Kurikulum 2013 untuk Siswa Kelas V SD Dengan Pendidikan Karakter

Analisis Nilai Karakter dalam Buku Tematik Terpadu untuk siswa kelas V SD terdiri dari 11 (sebelas) nilai karakter sebagaimana yang tertuang dalam Bahan Pelatihan Penguatan Metodologi Pembelajaran Berdasarkan Nilainilai Budaya untuk Membentuk Daya Saing dan Karakter Bangsa yang diterbitkan oleh Kementerian Pendidikan Nasional Badan Penelitian dan Pengembangan Pusat Kurikulum, yaitu: religius, toleransi, disiplin, kreatif, demokratis, rasa ingin tahu, semangat kebangsaan, menghargai prestasi, bersahabat, senang membaca, dan peduli lingkungan. Berikut adalah temuan data nilai pendidikan karakter dalam Buku Tematik Terpadu Kelas V SD sesuai Kurikulum 2013.

\begin{tabular}{|l|l|l|}
\hline Nilai Karakter & \multicolumn{1}{|c|}{ Halaman } & $\sum$ \\
\hline Religius & $\begin{array}{l}21,21,44,45,45,76,45, \\
103,159\end{array}$ & 9 \\
\hline Toleransi & $\begin{array}{l}21,22,22,23,23,37,58,81, \\
82,82,82,83,133,161\end{array}$ & 13 \\
\hline Disiplin & 182 & 1 \\
\hline Kreatif & $9,70,70,70,124,124,170$ & 7 \\
\hline Demokratis & $22,23,37,143,153$ & 5 \\
\hline Rasa Ingin Tahu & $2,113,121,124,133,183$ & 6 \\
\hline Semangat & $20,22,23,70,76,76$, & 11 \\
\hline Kebangsaan & $82,99,118,127,161$ & 4 \\
\hline Menghargai Prestasi & $23,117,118,130$ & \\
\hline Bersahabat & $20,37,146,149,149,184$ & 6 \\
\hline Peduli Lingkungan & $20,45,45,58,58,59,76,88$, & 29 \\
& $88,96,97,99,99,103,124$, & \\
\hline $125,142,144$ & \\
\hline
\end{tabular}

Tabel 1. Nilai Karakter dalam Buku Tematik Terpadu Kelas V SD Tema 1: Organ Gerak Hewan dan Manusia

Karakter "peduli lingkungan" menduduki peringkat paling atas, dengan temuan 29 data. Pada indikator "senang atau gemar membaca" adalah temuan data yang paling sedikit, yaitu 1 data. Elemen pendidikan karakter yang banyak/seringnya muncul dalam buku terpadu (tematik) kelas V SD di Bandar 
Lampung adalah 1) peduli lingkungan, 2) toleransi, 3) semangat kebangsaan, 4) religius, 5) kreatif, 6) rasa ingin tahu, 7) bersahabat, 8) demokratis, 9) menghargai prestasi, 10) disiplin, dan 11) senang membaca. Berikut dikemukakan nilai pendidikan yang terdapat dalam buku terpadu (tematik) kelas V SD.

Dari nilai religius, kita tidak boleh memaksakan suatu agama dan keperyaaan kepada orang lain, kita harus saling menghormati kebebasan dalam menjalankan ibadah dan mengakui kebesaran Tuhan atas segala ciptaannya. Perwujudan dari nilai toleransi yaitu menjaga hak orang lain yang berbeda agama untuk melaksanakan ajaran agamanya. Perilaku disiplin dalam menjaga kesehatan, khususnya organ tubuh dan menjaga kesehatan organ tubuh, termasuk organ gerak sebenarnya dapat dilakukan sejak kecil.

Karakter kreatif, yaitu perwujudan dari indikator membuat kalimat baru dari sebuah kata dengan membuat akronim dari kata "gurame" untuk usahanya membuat kerupuk dari singkong. Kata "Gurame" sama sekali tidak ada hubungannya dengan ikan gurame, tetapi gurame adalah singkatan dari Gurih, Renyah, Enak. Sikap demokratis, yaitu pada indikator sikap membiasakan diri bermusyawarah dengan teman-teman dan menerima kekalahan dalam pemilihan dengan ikhlas. Karakter rasa ingin tahu terdapat pada indikator bertanya tentang sesuatu yang terkait dengan materi pelajaran tetapi di luar yang dibahas di kelas.

Sikap atau semangat kebangsaan merupakan perwujudan dari Sila Keempat Pancasila, yaitu Nilai kerakyatan yang dipimpin oleh hikmat kebijaksanaan dalam permusyawaratan/perwakilan. Bentuk penghargaan terhadap prestasi seseorang mengenai "Ade Rai, Binaragawan Perkasa Indonesia”. Ade Rai adalah sosok pria perkasa yang sangat terkenal di Indonesia, bahkan di dunia; banyak sudah prestasi yang diraihnya, baik di tingkat nasional maupun internasional. Selanjutnya, salah satu ciri dari karakter bersahabat, yaitu aktif dalam kegiatan sosial. Kemudian, contoh bentuk cara memotivasi siswa dalam membaca.

Instruksi atau sub judul dalam buku tematik terpadu untuk siswa kelas $\mathrm{V}$, i, seperti klausa 'Ayo Membaca'. Hal itu difungsikan untuk memunculkan 


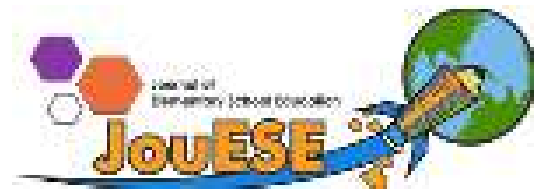

minat siswa dalam membaca, kegemaran yang dibiasakan, untuk kemudian menjadi budaya membaca. Terakhir, salah satu ciri dari karakter peduli lingkungan, yaitu peran siput yang memakan daun yang menjadikannya bagian/serpihan kecil sehingga mudah untuk diuraikan oleh bakteri pengurai.

\section{SIMPULAN}

Proses implementasi nilai pendidikan karakter di SDN 1 Gunung Terang, Bandarlampung terdiri dari tahap perencanaan, pelaksanaan, dan evaluasi. Perencanaan implementasi nilai-nilai pendidikan karakter meliputi kegiatan sosialisasi perangkat kurikulum, perencanaan tata tertib sekolah dan siswa, serta pegarahan dari bagian kurikulum mengenai perencanaan nilai karakter melalui pembuatan Silabus dan RPP pada proses pembelajaran di kelas. Pelaksanaan nilai karakter diwujudkan melalui proses pembelajaran di kelas, pengondisian sekolah, kebiasaan dan budaya karakter untuk menanamkan nilai karakter positif pada siswa. Pada saat pembelajaran, Implementasi karakter terintegrasi dalam setiap mata pelajaran yang mencakup tiga tahap, yaitu perencanaan, pelaksanaan, dan evaluasi pembelajaran. Penilaian karakter pada siswa yang terintegrasi dalam mata pelajaran merupakan nilai perilaku siswa yang dilakukan berdasarkan pengamatan perkembangan perilaku siswa saat kegiatan pembelajaran berlangsung.

Kesesuaian buku tematik terpadu Kurikulum 2013 untuk siswa kelas V SD dengan pendidikan karakter meliputi sebelas nilai karakter, yaitu: religius, toleransi, disiplin, kreatif, demokratis, rasa ingin tahu, semangat kebangsaan, menghargai prestasi, bersahabat, senang membaca, dan peduli lingkungan. Karakter Peduli lingkungan menduduki peringkat paling atas, dengan temuan 29 data. Kemudian, pada indikator Senang atau gemar membaca adalah temuan data yang paling sedikit, yaitu 1 data. Elemen pendidikan karakter yang banyak/seringnya muncul dalam buku terpadu (tematik) kelas V SD di Bandar Lampung adalah 1) peduli lingkungan, 2) toleransi, 3) semangat kebangsaan, 4) religius, 5) kreatif, 6) rasa ingin tahu, 7) bersahabat, 8) demokratis, 9) menghargai prestasi, 10) disiplin, dan 11) senang membaca. 


\section{DAFTAR PUSTAKA}

Brown, H. D. (2000). Principles of Language Learning Teaching. New York: Pearson Education.

Cunningsworth, Alan. (1995). Choosing Your Coursebook. Oxford: Heinemann. Efendi, Anwar. (2009). "Beberapa Catatan tentang Buku Teks Pelajaran di Sekolah". Jurnal Penelitian. INSANIA|Vol. 14|No.2|Mei-Ags 2009, hal. 320-333, Jurusan Tarbiyah STAIN Purwokerto.

Harmer, Jeremy. (2003). How to Teach English. Edinburgh Gate: Addison Wesley Longman Limited.

Kawuryan, Sekar Purbarini. (2013). Pengembangan Pendidikan IPS SD (Bahan Ajar Mata Kuliah). Yogyakarta: Jurusan PGSD Fakultas Ilmu Pendidikan, Universitas Negeri Yogyakarta.

Lickona, Thomas. (1991). Educating for Character: How Our School Can Teach. Respect and Responsibility. New York: Bantam Books. Mulyana, Agus. (2009). "Pendekatan Historiografi dalam Memahami Buku Teks". Makalah Seminar Nasional "Mendekonstruksi Permasalahan Pembelajaran Sejarah Di Sekolah', (Bandung: Jurusan Pendidikan Sejarah FPIPS UPI pada tanggal 19 Oktober 2009, 1-14

Siska, Yulia. (2018). "Implementasi Nilai Pendidikan Karakter dalam Pembelajaran IPS SD Kelas V di Bandarlampung". LENTERA: Jurnal Ilmiah Kependidikan, Vol. 11, No. 2, 2018, 31-40.

Sofyan, Herminarto. (1997). "Pedoman Umum Pengembangan Bahan Ajar Sekolah Menengah Kejuruan (SMK)", Yogyakarta: TIM Peneliti Bahan Ajar FPTK IKIP Yogyakarta. Tersedia (online) http:// fasilitas.itgo.com/ buku/PEDOA.htm, diunduh 22 Januari 2016) Sugiyono. (2012). Metode Penelitian Pendidikan Suatu Pendekatan Kuantitatif, Kualitatif, dan R\&D. Bandung: Alfabeta.

Sukmadinata, Nana Syaodih. (2013). Pengembangan Kurikulum Teori dan Praktek, cet. ke-3. Bandung: PT Remaja Rosdakarya.

Supriono, Yoyo. (2015). "Pembelajaran IPS dalam Kurikulum 2013". Artikel (Online), 02 Februari 2015, diunduh pada Januari 2017. 